\title{
The Effect of Appling Constructivist Teaching Methods on Children Ability in Critical Thinking. BY
}

Rehab J. Agzagee, M.Ed.

Department of Human Sciences and Design

Faculty of Childhood Studies, King AbduAziz University Jeddah, Saudi Arabia

Doi: 10.12816/jacc.2020.68459

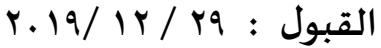

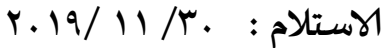

\section{Abstract:}

The study will determine the impact of implementing Constructivist teaching and learning methods to develop critical thinking abilities of Kindergarten children in Saudi Arabia. The study will adopt Pragmatism approach to emphasize the essential aspects, which the practice should contain to assure delivering the effective practice to the children. The study intends to conduct a practical action research using a randomly sample of Kindergarten children Saudi Arabia. The researcher will use mix methodology including: observations of the teachers' practices, and focus group discussions in the final stage. Initial primary exploratory research was conducted to determine the participations who were interested in applying Constructivist Teaching Methods. Then Observation will be applied for two groups (treatment and nonintervention) to explore the effect of Constructivist Teaching methods on developing critical thinking of the children. Focus group discussions will be applied for teachers to identify their perspectives of certain factors related to acquiring critical thinking skill. The main aim is to explore perceived differences in both groups of children which might indicate differences in developing critical thinking. this will help us to investigate the impact of applying Constructivist Teaching and learning methods. 


\section{Introduction}

The development of constructivist theory of learning has attracted my attention for several years. The main theme in my framework is constructivism as a theory about knowledge and learning. Jean Piaget launched the key idea of constructivism a long time ago. Fosnot (1996) pointed out that constructivism "was the idea that what we call knowledge does not and cannot have the purpose of producing representations of an independent reality, but instead has an adaptive function" (p.3). Piaget's adaptive idea started from the study of biology, in which animals try to survive with environmental difficulties.

The discovery learning of Piaget influences constructivist educators in encouraging students to learn through manipulating the subject matter and the objects in their experiments. Therefore, the students will be able to develop logical and analytical thinking skills. As well, John Dewey stimulated constructivist theory with learning through experiences in field trips and outdoor activities. In addition, Howard Gardner provided educators with significant views of cognitive development of the child. Gardner advocated that learning would be more effective if we, as educators, are aware of the eight intelligences in each student. Piaget, Dewey and Gardner were the foundational researchers in the development of constructivist theory. Therefore, their legacies advocate the methods of creative constructivist teaching and learning (Fogarty, 1999).

These researchers view constructivist learning as "a selfregulated process of resolving inner cognitive conflicts that often become apparent through concrete experience, collaborative discourse, and reflection" (Brooks \& Brooks, 1993, p.vii).

The main goal of constructivist learning is to stimulate students, to challenge their abilities and cognitive skills through an enriched environment, and to motivate them to use all their sensors to discover the truth. 
As educators, we can build the main strategies of the constructivist paradigm to fit in teaching both adults and children. For example, the teacher allows children to discover several essential concepts from one large idea instead of following a directed curriculum. As well, the professor and the students share the individual perspectives; the teacher provides the children with the power to choose their interests to make connections, to reformulate ideas, and to reach a conclusion by themselves (Brooks \& Brooks, 1993). Certainly, Hughes, Kooy, and Kanevsky (1997) stated that the professor encourages students to construct knowledge through reflection and interaction with the presented material. In short, the teacher and the professor will set the first block of a constructivist building.

In fact, constructivism and the 5E model science lesson (2004) pointed important issue of applying the organization from the teachers and professors to enroll the students in reflection, interaction, and investigation. In addition, it requires certain group and individual learning plans. preparation of an enriched constructivist environment requires knowledge of differentiated teaching strategies, multiple intelligences, valuable procedures to implement effective curriculum, the establishment of a stimulated and motivated environment, and production of organized learning plans for students.

\section{Purpose}

The main purpose of this article is to discover how constructivism teaching and learning strategies can affect the learning process through developing critical thinking ability of the children with the age-group 5 to 6 years from teacher's perspective. This study will exhibit future plans to apply constructivist approach in the teaching and learning strategies.

\section{Definition of Terms}

Critical thinking: A special way of considering issues or topics through using several lenses to clarify certain perspectives 
Constructivism: A theory about knowledge and learning that attempts to reform education based on experimentations, questions, investigations, and syntheses

Teaching: The professional process of delivering knowledge to achieve personal growth

\section{Literature Review}

\section{The Goal of Education}

In my opinion, the goal of education is to develop, to increase, and to grow successfully. The goal of education is to positively transform the whole student from situation to another. In fact, to complete this transformation effectively, the student must have a strong motivation. The role of the teacher is to stimulate this motivation through differentiated teaching strategies to enrich the environment and to use curricula. Therefore, the education process focuses on the students' needs and the role of the teacher is to determine their needs at each stage of development. For example, teaching children requires that teachers to create attractive, valuable, and life activities starting from "posing questions about what they want to know". Today, we refer to this method of instruction as the problem-solving or inquiry method" (Sadovnik, Cookson, \& Semel, 2006, p. 175). Developing problem-solving skills helps to discover new concepts through life experiments. Bayles (1966) explained that the progressive teacher encourages students how to think, in order to foster ideas. Reflective thinking is a kind of problem-solving. Reflective thinking helps students to not only follow the teacher's thinking, but rather to develop their own ideas and explanations.

Webb's views (as cited in Hayes, 2006) about progressive methods in education are similar to what Dewey advocated in the learning by practicing through experience, not through memorizing the curriculum. As well, the primary goal of the school should be to promote children and give them chances to participate in a 
democratic society. In addition, the learning process must cover the child's intellectual needs, physical needs and emotional needs. curriculum must focus on the students needs, but it should be under flexible structures as a kind of organization especially, for adults. Certainly, Gardner (as cited in Sadovnik et al., 2006) pointed out that Dewey's curriculum has an effective balance between the traditional disciplines and the child's interests. My philosophy is that the student chooses the material and the teacher creates the effective process to allow students to achieve the expectation goals independently. Bayles (1966) stated that the role of the teacher is essentially to guide and direct the class to encourage students to learn by their selves.

Certainly, Miller's (1983) orientation to curriculum introduces three curriculum perspectives which are transmission, transaction, and transformation. As well, Sadovnik et al. (2006) found that there are two traditions of teaching. The first tradition is the mimetic, which relates to a conservative model; the second is the transformative, which agrees with the progressive model. Through my research, I can relate the mimetic tradition to the transmission perspective. In my opinion, the transformative tradition is considered to be a successful teaching process. Transformative means change in form, appearance and character. Hoy and Miskel (2008) explained that "Transformational criteria are the quantity, quality, and consistency of the internal processes and structures that transform the inputs to outcomes" (p. 300). Sadovnik et al. (2006) stated that this kind of teaching process makes students different in several ways because the teacher uses several theories of teaching. Furthermore, the transformative process links the teacher and the student together. This learning style follows the dialectical method. As well, Sadovnik et al. found that.

The dialectical method, which involves the use of questioning, is at the core of its methodology. Derived from 
teaching methods of Socrates, as presented in the dialogues of Plato, and given philosophical grounding in the works of John Dewey, transformative educators believe that all teaching begins with the active participation of the student and results in some form of growth. (p. 275)

For more information, Sadovnik et al. pointed out that the talented teachers can make a difference, as they trust the student's ability and the style of learning. Therefore, they can affect the school philosophy. Students will be at the core of the learning and will develop in thinking, considering, analyzing and concluding skills in the classroom.

\section{Constructivist Educational Visionaries}

The perspective of constructivist learning focuses on resolving the cognitive conflicts based on "hands-on experimentation and learner-generated questions, investigations, hypotheses, and arts reform" (Brooks \& Brooks, 1993, p. vii). The concept of constructivism in the field of education was launched from how we connect knowledge from our actions with our experience of the world to develop new concepts and ideas. In fact, everyone makes conclusions of the new experience based on what he or she had previously experimented. Fosnot (1996) implied that knowledge should be treated as actions that are functioning in the subject's experience. Piaget's concept is that each understanding relies on our thinking ability to cope with different perceptions and our experiences (Brooks \& Brooks, 1993).

Fogarty (1999) began the article "Educational Leadership" with a paragraph building a foundation of constructivist theory "These are 'architects of the intellect' who design exquisite learning experiences for eager minds. Their mission is to create learning experiences that invite students to construct knowledge [italic added] and to make meaning of their world" (p. 76). These researchers are educational designers who influenced my thoughts 
about constructing a new method of learning. These researchers are the following: Jean Piaget, John Dewey, and Howard Gardner. Dewey emphasized learning through experience. Furthermore, Dewey's work was influenced by the child-centered approach. Sadovnik et al. (2006) pointed out that Dewey disagreed with the formal instructions in the class. The tasks in this class do not yield to specific time as we find this instruction in the traditional class. Indeed, Dewey encouraged the students to move freely about the classroom and work individually or in groups. The furniture in Dewey's class is informal because his class does not require tables and chairs unless they are needed for a group work. As a result, the learning style in Dewey's class flows naturally.

Gardner added his rainbow of cognitive touches to constructivist theory. Gardner in his multiple intelligence theory investigated eight ways of understanding and learning. The eight intelligences are the following: verbal, logical, spatial, musical, kinesthetic, interpersonal, intrapersonal, and naturalist. Each child has special keys to open his or her learning window. In fact, I found in Sylvester's study (as cited in Jasmine, 1996) an effective point which explained that each child holds all the eight intelligences, but some intelligences are stronger than others. Therefore, the child will experience more success in the dominant area. The excellent structures help the educator to emphasize the weak areas, but still these areas might never be as strong as the high-level intelligences.

\section{Teaching Methods in a Constructivist Class}

In a constructivist class, the teacher sets a suitable environment to let students use their experiences to integrate new ideas. As well, the teacher gives the child chances to decide, to discover, to challenge, to create art, and to move. Furthermore, the teacher helps student to integrate unknown ideas from known ideas "Piaget's concept". The sun will rise with a beautiful rainbow holding eight bright colors. Each color has a specific successful 
area. Truly, arranging classrooms in a particular structure with certain activities can achieve student's intelligences. Therefore, the teacher will know each one's door to open the interesting learning world "Gardner's idea". Asking the students what they already know, what they want to know and what they are interested in is the first step to create a child-centered class, and the first try to let the wind move smoothly between students and the teacher. In addition, the teacher helps each student touch and play with the learning ball experimentally. Furthermore, the teacher lets the students dig their ground to plant their learning tree. Then, they wait for the generous rain to raise their flowers. The teacher shares the curriculum with the students. Finally, the teacher helps students to reform, shape and evaluate their learning opportunities "Dewey's concept" (Pollishuke \& Schwartz, 1990).

The world we see is "our" world, and the way we see it is the "right" way.

Julia Jasmine

\section{The Effective Teacher}

\section{$\infty 900900$}

The one who influences the students, follows successful methods in teaching, and encourages students to use all their skills in learning is considered to be an effective teacher. The effective educator is the one who influences people due to special talents and unique skills. Certainly, the effective teacher believes in changing, correcting, and reforming the learning environment to reach specific goals. A Sadovnik, Cookson, and Semel, (2006) stated, "a talented and dedicated teacher can make difference" (p. 458). In fact, the teachers make difference when they change students positively through a successful philosophical dimension of teaching. This ability to bring about change is called the transformative tradition.

The strong link between teacher and students will encourages teacher to trust students' abilities in reaching their 
goals by using different skills. When the teachers believe that every one possesses strong areas and each one has special way to learn the same concept, the teachers will plant in the students' hearts a great self-confidence of their abilities. Therefore, their self-reliance will be the ground of their effective learning. In my opinion, these teachers are the ideal educators in the school because they believe that each one has the desire of learning and their roles are trying to stimulate each student's eagerness. In addition, Sadovnik et al. describe the effective teacher's role: "Second, if teachers expect all students to learn and excel, they can and do. Third, it is possible to institutionalize the effective teaching of one teacher in to an overall school philosophy" (p. 458). Truly, the ideal teachers' approach will be a positive effect on the school philosophy and excellent models for other teachers. Research Questions

1. What are the essential strategies of designing Constructivism Teaching Methods for children?

2. How Constructivism Teaching Methods affect the children's ability of Critical Thinking?

3. What are the teachers' perspectives on applying Constructivist Teaching Methods?

\section{Methodology \\ Justifications}

An action research design is selected to address a practical issue of (Implementing a Constructivist Teaching and Learning Methods), the main goal of the research is to determine the effectiveness of Applying Constructivist Teaching and Learning Methods on children's ability of critical thinking. Starting with highlighting the teachers' philosophy on Constructivist Teaching and Learning Methods to implement the strategy through conducting an expletory study by using a structured survey to identify the approximate quantity of $\mathrm{KG}$ teachers who are 
interested in apply one of constructivist teaching method in the class (Information gathering stage).

The researcher needs contribution from the teachers to develop the teaching strategy because "Educators can test their own theories and explanation about learning, examine the effects of their practices on students, and explore the impact of approaches on parents, colleagues, and administrators within their schools" (Creswell, 2008, p597). The strategies behind the design will start with two groups of KG children: the first group will receive Constructivist Teaching Methods (treatment group) and the second group will receive traditional teaching methods (nonintervention group). Systematic observation will be used in both groups to identify the essential strategies of designing Constructivism Teaching Methods for children and How Constructivism Teaching Methods affect the children's ability of Critical Thinking (Identification Stage). Then Developing a follow up session to reflect the teachers' experiences and perspectives through focus group in order to examine the efficiency of applying Constructivism strategies and key element of encouraging children to develop critical thinking.

\section{Conclusions}

Constructivist teaching and learning methods as a theory focus on the hidden curriculum which holds the strategy of presenting the knowledge, the methods of organizing the classroom environment, and the steps in creating a trustful relationship between teacher and students. Brooks and Brooks (1993) stated that "A constructivist framework challenges teachers to create environments in which they and their students are encouraged to think and explore" (p. 30). Therefore, becoming a constructivist teacher demands strong effort to focus on the process more that the result. In addition, Brooks and Brooks emphasized that the curriculum focus around big ideas which open several entries of learning for students. Some will identify the problem, others will 
analyze facts through following specific principles, and others understand ideas through connection with their experiences. Hence, the learning began from student and the teacher is the one who structures and organizes the learning process. Practicing constructivist teaching and learning strategies will be challenging with a solid curriculum and large classes but beginning with teaching small groups and differentiating teaching styles will fill some holes. If we implement the previous given example, which was giving students chance to present the materials in their way, this opportunity deepens the understanding of following constructivist teaching methods. Zahorik (1995) explained that in this method, the students have an active view in taking responsibility to decide for themselves; for instance, selecting interesting articles or topics. Certainly, these articles have valuable knowledge and evidence which hold a foundational view. Zahorik stated that

Foundational knowledge consists of those powerful, collective constructions that have been developed over time through sharing, critiquing, and revising....The goal of schools, from this position, is to have students acquire this foundational knowledge and to fit it into their existing knowledge structures or adjust their structures to accommodate it. (p. 34)

Hence, in our real education life, curriculum is considered as a foundational knowledge which students must possess. From my standpoint, believing on the activity view and foundational knowledge is the suitable approach of applying constructivist theory with a standard curriculum and large classes. In most cases, teachers, professors, and educators face difficulties in reforming curriculum; so applying discovery teaching and learning methods provides great chances for students to be involved. Zahorik pointed out that the teacher can structure their lessons through activity which help students to present their views. 
Constructivist methods in discovering knowledge through experience, practicing, using knowledge, and reflecting on it inspire me to practice these strategies in large classes. Applying this creative strategy could be a challenge for me at first, but I believe that these steps will affect the learning process positively. Constructing knowledge with undergraduate and elementary students is my career goal focus.

\section{References}

Bayles, E. E. (1966). Pragmatism in education. New York: Harper \& Row.

Brooks, J. G., \& Brooks, M. G. (1993). The in search of understanding: The case for constructivist classrooms. Alexandria: Association For Supervision and Curriculum Development.

Constructivism and the 5E model science lesson. (2004), Retrieved November 22, 2007, from http://cte.jhu.edu/techacademy/fellows/Ulrich/webquest/mk und.htm.

Creswell, J. W. (2008). Educational Research; planning, conduction, and evaluating quantitative and qualitative research $\left(3^{\text {rd }}\right.$ ed.). Upper Saddle River, New Jersey: Pearson Education Ltd.

Fogarty, R. (1999). Architects of the intellect. Educational leadership. 57(3), 76-78.

Fosnot, C. (Ed.). (1996). Constructivism: Theory, perspectives, and practice. New York: Teachers College Press.

Hayes, W. (2006). The Progressive education movement. Lanham, MD: Rowman \& Littlefield.

Hughes. H., Kooy. M., \& Kanevsky. L. (1997). Dialogic reflection and journaling. The Cleaning House. 70(4), 187-190. 
Hoy, W. K., \& Miskel, C. G. (2008). Educational administration: Theory, research, and practice $\left(8^{\text {th }} \mathrm{ed}\right)$. New York, NY: The McGraw-Hill Companies, Inc.

Jasmine, J. (1996). Teaching with multiple intelligences. Westminster, CA: Teacher Created Materials.

Miller, J. (1983). The educational spectrum: orientations to curriculum. New York: Longman.

Pollishuke, M. \& Schwartz, S. (1990). Creating the child-centered classroom. Toronto, ON: Irwin publishing.

Sadovnik, A. R., Cookson, P. W., \& Semel, S. F. (2006). Exploring education: An introduction to the foundations of education (3rd ed). Boston, MA: Allyn and Bacon.

Zahorik, J. (1995). Constructivist Teaching. Bloomington, Indiana: The Phi Delta Kappa Educational Foundation. 